11. Дубков Е.П. Демократические основы организации советской адвокатуры: автореф. дис. ...канд. юрид.наук. М., 1965. $-22 \mathrm{c}$.

12. Осадчук Е.И. История зарождения и развития адвокатуры в царской России // Ученые записки Орловского государственного университета. №4 (54), 2013. - С. 81-88.

13. Тютрюмов И.М. Законы гражданские с разъяснениями Правительствующего Сената и комментариями русских юристов. Составил И.М. Тютрюмов. Книга четвертая. Издание 1900 года, по прод. 1906 и 1908 годов. // СПС «КонсультантПлюс» (Дата обращения: 20.10.21).

14. Юношев С.В. Очерк развития адвокатуры в России // Юридический вестник Самарского университета. Том 4. № 1. 2018. - C. 85-91.

\title{
Медведев С.С., Каспаров Э.А. \\ Уголовно-правовые средства борьбы с контрабандой алкогольной и табачной продукции на территории России
}

Кубанский государственный аграрный университет им. И. Т. Трубилина

(Россия, Краснодар)

doi: 10.18411/trnio-12-2021-186

\section{Аннотация}

Автором анализируется существующие уголовно-правовые средства по борьбе с контрабандой алкогольной продукции и табачных изделий. Актуальность данной темы обусловлена тем, что контрабанда затрагивает важнейшие сферы государства, причиняя вред экономике страны, жизни и здоровью граждан. Эта незаконная деятельность в России растёт с каждым днём, приобретая более крупные масштабы и организованность в совершении данных преступлений. Таким образом, совершение преступлений данной направленности не является редкостью, в связи с чем, наличие правовых средств по борьбе с ними являются объективной необходимостью. Автор формулирует и обосновывает вывод о том, что существующие средства по борьбе с контрабандой не являются совершенными, а нормы, действующие в данной сфере, нуждаются в изменениях и дополнениях. В качестве выводов автором сформулированы рекомендации по решению вышеперечисленных проблем.

Ключевые слова: алкогольная продукция, табачные изделия, контрабанда, граница, крупный размер.

\section{Abstract}

The author analyzes the existing criminal legal means to combat the smuggling of alcoholic beverages and tobacco products. The relevance of this topic is due to the fact that smuggling affects the most important areas of the state, causing harm to the country's economy, the life and health of citizens. This illegal activity in Russia is growing every day, acquiring a larger scale and organization in the commission of these crimes. Thus, the commission of crimes of this orientation is not uncommon, and therefore, the availability of legal means to combat them is an objective necessity. The author formulates and substantiates the conclusion that the existing means of combating smuggling are not perfect, and the norms in force in this area need to be changed and supplemented. As conclusions, the author formulated recommendations for solving the above problems.

Keywords: alcoholic beverages, tobacco products, counter-band, border, large size.

Понятие «контрабанда» появилось в период правления Петра I и означало «против правительственного указа». Аналогичным образом трактуется данное понятие в толковых словарях, в которых контрабанду понимают, как тайный и незаконный провоз товаров и иных предметов через государственную границу определенного государства [8]. Действительно, под контрабандой стоит понимать незаконное перемещение через государственную границу товаров и продукции в целях ее дальнейшей незаконной реализации. В настоящее время, в качестве предмета контрабанды нередко выступает 
алкогольная продукция и табачные изделия, что обусловило выделение данного деяния в отдельную статью Уголовного кодекса РФ (далее-УК РФ) [4].

Так, ч.1 ст. 200.2 УК РФ указывает на такое преступление, как незаконное перемещение через таможенную границу Таможенного союза алкогольной продукции и (или) табачных изделий в крупном размере. Как отмечается в Постановлении Пленума ВС РФ от 27.04.2017 года № 12 «О судебной практике по делам о контрабанде» под незаконным перемещением через таможенную границу стоит понимать перемещение товаров или иных предметов вне установленных мест или в неустановленное время работы таможенных органов в этих местах [9]. Также по незаконное перемещение попадают сокрытие товаров от таможенного контроля, недостоверное декларирование, использование документов, использующих недостоверные сведения. Квалифицированными видами данного преступления является его совершение должностным лицом с использованием своего служебного положения, организованной группой и группой лиц по предварительному сговору. Говорить о крупном размере можно тогда, когда стоимость алкогольной продукции и (или) табачных изделий превышает двести пятьдесят тысяч рублей. Стоит отметить, что совершение данного преступления на практике не является редкостью.

Кроме того, количество таких преступлений планомерно возрастает, а общественная опасность состоит в том, что незаконному перемещению в большинстве случаев подвергается контрафактная продукция, представляющая угрозу для жизни и здоровья граждан. Прежде чем определять средства борьбы с контрабандой алкогольной продукции и табачных изделий, стоит выявить основные причины роста данного вида преступления.

Полагаем, что таких причин можно выделить несколько. Во-первых, это стремительный рост акцизов и высокие минимальные цены на легальную продукцию порождает спрос на контрафакт. Во-вторых, это увеличение числа лиц, которые специализируются на завозе дешевого и нередко контрафактного алкоголя на территорию Российской Федерации. В-третьих, это несоразмерность уголовных наказаний и размера выручки, которую получают лица, занимающиеся контрабандой алкогольной продукции и табачных изделий. И, наконец, в-четвертых, причина видится в том, что сегодня имеет место недостаточная правовая защита производителей данной продукции на территории нашей страны.

Представляется, что именно данные причины предопределили внедрение со стороны законодателя дополнительных мер, направленных на борьбу с контрабандой алкогольной продукции и табачных изделий. Особое значение в данном аспекте приобретают нормативные акты, которые регулируют данную область и устанавливают ответственность за совершение данного преступления. К их числу относятся как международные акты, так и документы Таможенного Союза, а также акты отечественного законодательства. В результате анализа правовой базы можно заключить, что сегодня наблюдается разрозненность в регулировании данных отношений, а единый документ, систематизирующий вопросы ответственности за контрабанду, в настоящее время отсутствует. Одновременно с этим, нельзя не отметить попытки законодателя существенно оптимизировать законодательство в данной сфере посредством внесения ряда изменений. В частности, можно отметить нововведения Федерального закона от 31.12.2014 года № 530-Ф3 [1]. Так, данным законом были усилены меры по противодействию контрабанде алкогольной и продукции и табачных изделий, а также их обороту в дальнейшем, так как в УК РФ введена ст. 200.2 УК РФ, установившая максимальное наказание за совершение данного преступления 12 лет лишения свободы. Наличие данной статьи оценивается весьма положительно, так как основным методом уголовно-правой борьбы с контрабандой в данном случае выступает ужесточение уголовной ответственности за совершение указанного преступления. Как следствие, посредством уголовно-правовой меры в данном случае законодатель проявил стремление решить такие задачи, как охрана интересов Российской Федерации, ее экономических интересов, обеспечение законного порядка осуществления предпринимательской деятельности, охрана рынка от контрафакта. Кроме того, с помощью 
дополнения УК РФ данной статьей появились возможности для пресечения теневого оборота табачных изделий и алкогольной продукции, недопущения недобросовестной конкуренции, а также для обеспечения безопасности и качества товаров.

Одновременно с этим в качестве эффективного уголовно-правового средства борьбы с контрабандой алкогольной продукции и табачных изделий видится налаженное взаимодействие между таможенными и следственными органами. Данное взаимодействие предопределено решением оперативно-тактических задач, необходимых для расследования указанного преступления. К числу таких задач можно отнести как документирование преступных действий, так и выявление организованных групп и групп, действующих по предварительному сговору. Направления развития данного взаимодействия видятся в разработке и принятии совместных документов, которые будут определять формы, методы и сроки осуществления совместных действий. Кроме того, сегодня требуется постоянный и взаимный обмен информацией, а также совместное проведение оперативно-розыскных мероприятий и операций. Взаимодействие ФТС и ОВД сегодня нельзя признать совершенным в связи с чем, некоторые его аспекты нуждаются в совершенствовании [6].

Также в рамках настоящего исследования стоит акцентировать внимание на том, что борьба с контрабандой алкогольной продукции и табачных изделий будет эффективной только в том случае, если действия субъектов будут правильно квалифицированы. Так, не все сырье, которое провозится через таможенную границу, относится к алкогольной продукции. Руководствоваться в данном случае стоит Постановлением Правительства РФ от 09.11.2017 года № 1344 [5], а также разъяснениями, содержащимися в Федеральном законе от 22.11.1995 года № 171-Ф3 [3]. Согласно данному закону, к алкогольной продукции относят спиртные напитки, винные напитки, пиво и напитки, которые изготавливаются на основе пива, сидр, медовуха и пуарэ. Так как предметом преступления, предусмотренного ст. 200.2 УК РФ является алкогольная продукция и табачные изделия, не относится к данному преступлению перемещение этилового спирта, а также перемещение спиртосодержащей продукции с содержанием этилового спирта более 0,5 \% объема готовой продукции. Как следствие незаконное перемещение данных веществ через таможенную границу должно получать несколько иную уголовно-правовую оценку. Как правило, данные действия квалифицируются по ст. 226.1 УК РФ. Что касается табачных изделий, стоит отметить, что к ним относят все виды табака, что прямо следует из содержания Федерального закона от 22.08.2008 года № 268-Ф3 [2]. Таким образом, на квалификацию деяния как контрабанды табачных изделий не зависит конкретный вид изделия, будь то жевательный табак, нюхательный табак.

Как уже отмечалось ранее, незаконное перемещение - это перемещение вне рамок установленных мест и процедур, что также приобретает значение для правильной квалификации совершенного деяния, так как данные действия нередко направлены на умышленное сокрытие от таможенных органов перевозимой продукции. Под сокрытием в данном аспекте стоит понимать такие действия виновных лиц, которые направлены на то, чтобы существенно затруднить обнаружение продукции, незаконно перемещаемой через границу. Как правило, виновные лица организуют тайники, не позволяющие определить вид продукции посредством обычного визуального осмотра, а также путем осмотра с помощью специальных технических устройств и приспособлений [7]. Данные моменты позволяют говорить о наличии умышленной формы вины при совершении данного вида преступления и о возможности квалификации деяния в качестве контрабанды алкогольной продукции и табачных изделий. Виновные лица не применяют сокрытие в случаях совершения преступления с использованием служебного положения, однако данные действия не случайно составляют квалифицированный вид данного преступления, а ответственность за его совершение ужесточается.

Стоит акцентировать внимание на том, что ст. 200.2 УК РФ, как прямо следует из ее содержания, не будет распространяться на случаи незаконного перемещения алкогольной продукции или табачных изделий через государственную границу Российской Федерации, 
которая не совпадает с таможенной границей Таможенного Союза. Во многом это обусловлено тем, что в связи с принятием Таможенного кодекса Таможенного Союза был убран таможенный контроль на внутренних границах государств-участников ТС. Полагаем, что на этом не случайно акцентирует внимание законодатель, так как в диспозиции ст. 200.2 УК РФ акцентируется внимание на незаконном перемещении через границу Таможенного Союза. Полагаем, что данный момент также стоит учитывать при квалификации деяния по ст. 200.2 УК РФ.

Таким образом, правильная квалификация действий виновных лиц также играет особую роль в борьбе с данным видом преступности, так как наказание должно быть соразмерным и учитывать квалифицированные признаки того или иного преступления.

Стоит принимать во внимание то, что согласно примечанию 2 к ст. 200.2 УК РФ, при расчете размера стоимости незаконно перемещенной алкогольной продукции или табачных изделий из всей стоимости незаконно перемещенной продукции и изделий исключается часть стоимости указанных товаров, которая разрешена к перемещению без декларирования или была задекларирована. Полагаем, что указанное правило также должно находить свое распространение на конфискацию алкогольной продукции и табачных изделий, выступающих в качестве предмета незаконного перемещению через таможенную границу ТC в крупном размере. Как следствие, принудительному и безвозмездному изъятию и обращению в собственность государства не должна подлежать такая часть алкогольной продукции и табачных изделий, которая разрешена перемещению без декларирования или была задекларирована. В настоящее время правила такого рода нет, что видится пробелом действующего законодательства.

Также хотелось бы обратить внимание на то, что в ст. 200.2 УК РФ нет такого признака или примечания, как контрабанда в особо крупном размере, что также видится определенным законодательным упущением. Сегодня большинство преступлений экономической направленности классифицируются на преступления, совершенные в крупном и особо крупном размере. Ситуация осложняется тем, что, как показал анализ судебной практики, контрабанда алкогольной продукции и табачных изделий нередко совершается в достаточно крупных размерах, так как стоимость изъятой продукции составляет миллионы рублей. В связи с этим, отсутствие дифференциации ответственности лица в зависимости от объема алкогольной продукции и табачных изделий едва ли можно признать положительным. Более того, в подтверждение данного вывода приведем тот факт, что квалифицированными признаками деяния, которое предусмотрено ст. 200.2 УК РФ, является его совершение должностным лицом, группой, в том числе, организованной группой. В иных статьях главы 22 УК РФ данные признаки соответствуют совершению деяния в особо крупном размере, что видно из анализа таких статей, как ст. 194 УК РФ, ст. 171 УК РФ и других. Таким образом, внесение предложенных дополнений и изменений в УК РФ является объективной необходимостью.

$$
* * *
$$

1. Федеральный закон от 31 декабря 2014 г. N 530-Ф3 «О внесении изменений в отдельные законодательные акты Российской Федерации в части усиления мер противодействия обороту контрафактной продукции и контрабанде алкогольной продукции и табачных изделий» // Собрание законодательства РФ. - 2015. - N 1 (часть I). - Ст. 83.

2. Федеральный закон «Технический регламент на табачную продукцию» от 22.12.2008 N 268-Ф3 // Собрание законодательства РФ. - 2008. - N 52 (часть I). - Ст. 6223.

3. Федеральный закон от 22.11.1995 года № 171-Ф3 (последняя редакция) // "О государственном регулировании производства и оборота этилового спирта, алкогольной и спиртосодержащей продукции и об ограничении потребления (распития) алкогольной продукции Собрание законодательства РФ. - 1995. - N 48. - Ст. 4553.

4. Уголовный кодекс Российской Федерации от 13.06.1996 N 63-Ф3 (последняя редакция) // Собрание законодательства РФ. - 1996. - N 25. - Ст. 2954.

5. Постановление Правительства РФ от 09.11.2017 N 1344 «Об утверждении перечней пищевой продукции, которая произведена с использованием или без использования этилового спирта, произведенного из 
пищевого сырья, и (или) спиртосодержащей пищевой продукции, с содержанием этилового спирта более 0,5 процента объема готовой продукции, не относящейся к алкогольной продукции» // Собрание законодательства РФ. - 2017. - N 47. - Ст. 6981.

6. Вольдимарова Н.Г., Актуальные проблемы уголовной ответственности за экономические преступления: монография. - М.: Проспект, 2020-56 с.

7. Поляков Р.А., Контрабанда алкогольной продукции и (или) табачных изделий: основания уголовной ответственности и данные о практической реализации // Международный журнал гуманитарных и естественных наук. - 2020. - № 45. - С.155-157.

8. Филлипова Е.О., Контрабанда: история развития уголовно-правовых норм об ответственности за контрабанду в таможенной сфере и меры ее предупреждения // Балтийский гуманитарный журнал. - 2019. № 2(27). - С.183-187.

9. П Постановление Пленума ВС РФ от 27.04.2017 года № 12 «О судебной практике по делам о контрабанде» // Бюллетень ВС РФ. - 2017. - N 6.

\section{Никитина В.A. \\ Защита семейных прав \\ Кубанский государственный аграрный университет им. И. Т. Трубилина \\ (Россия, Краснодар)}

doi: 10.18411/trnio-12-2021-187

Научный руководитель Кудрявцеева Л.В.

\section{Аннотация}

Работа направлена на рассмотрение и изучение защиты семейных прав, сущности его судебного порядка. Определяется его место в общем механизме защите прав, выявляются его специфические черты и проблемы в реализации, а также пути их решения. Ведь Семья неотъемлемая часть современного общества. Его роль в удовлетворении человеческих потребностей: материальных, моральных и духовных. Семья принадлежит к важным социальным ценностям, поскольку от ее благосостояния зависит состояние общества. В свою очередь, задача государства - защитить семью, материнство, отцовство и детство. Данная тема весьма актуальная, так как до сегодняшнего времени ей не уделялось достаточного внимания. Важен не только теоретический, но и практический аспект данного вопроса.

Ключевые слова: семейное право, суд, права и обязанности, право, защита семейных прав.

\section{Abstract}

The work is aimed at reviewing and studying the protection of family rights, the essence of its judicial order. Its place in the general mechanism of protection of rights is determined, its specific features and problems in implementation, as well as ways of solving them, are identified. After all, the Family is an integral part of modern society. Its role in satisfying human needs: material, moral and spiritual. The family belongs to important social values, since the state of society depends on its well-being. In turn, the task of the state is to protect the family, motherhood, fatherhood and childhood. This topic is very relevant, since until now it has not received sufficient attention. Not only the theoretical, but also the practical aspect of this issue is important.

Keywords: family law, court, rights and obligations, law, protection of family rights.

Семья - неотъемлемая часть современного общества. Его роль в удовлетворении человеческих потребностей: материальных, моральных и духовных. Семья принадлежит к важным социальным ценностям, поскольку от ее благосостояния зависит состояние общества. Задача государства - защитить семью, материнство, отцовство и детство [1].

Защита семейных прав осуществляется судом по правилам гражданского судопроизводства [2]. Получается, что судебная система определяется как единая и основополагающая в устройстве защиты семьи и ее прав. 